\title{
Determining the Dominant Personality Traits of Construction Teams for Proactive Dispute Management
}

\author{
Mabaruka Danja, Yusuf Joe Gandu, Abdullahi Muhammed \\ Department of Quantity Surveying, Ahmadu Bello University, Zaria, Nigeria \\ Email: yusufgandu@yahoo.com
}

How to cite this paper: Danja, M., Gandu, Y.J. and Muhammed, A. (2021) Determining the Dominant Personality Traits of Construction Teams for Proactive Dispute Management. Open Access Library Journal, 8: e7162.

https://doi.org/10.4236/oalib.1107162

Received: January 20, 2021

Accepted: March 1, 2021

Published: March 4, 2021

Copyright $\odot 2021$ by author(s) and Open Access Library Inc.

This work is licensed under the Creative Commons Attribution International License (CC BY 4.0).

http://creativecommons.org/licenses/by/4.0/ (c) (i) Open Access

\begin{abstract}
Construction dispute must be properly managed or else it will mar projects success by its negative impacts. The challenge in managing construction dispute aggravates by virtue of the diversity in the background of people who come together to deliver projects during procurement process. People could have distinct personality traits which come to bare in the course of interactions. While some traits in individuals enhance dispute management, others complicate and prolong the dispute management process. Of recent, it has been found that dispute increasingly takes longer time to resolve. One area that can bring improvement is a proactive approach in dispute management. The knowledge of the dominant traits among construction disputants will enhance proactive management. The purpose of this research therefore is to enhance proactive dispute management by determining the dominant personality traits in construction teams that could explain difficulty in dispute management. Seven personality traits were identified and a questionnaire administered through stratified random sampling process among clients, consultants and contractors teams. The research computed the mean values and used $t$ distribution to test the level of significance of identified traits among-the client, consultants and contraction teams. The results of the analyses found that there are distinct traits among the teams. Clients are dominating during dispute, the consultants are obliging and integrating, while contractors avoid dispute situations. The clients and contractors' traits are unhealthy to dispute management. However, all parties are found to have a common tendency to compromise during dispute situation. Knowledge of this will enable better planning as well as strategies developed for enhanced dispute management. In dispute management, strategy should focus on aspects that can cause a compromising stance among disputants while putting into cognizance the unique traits, characteristics or behavior of each team during dispute. Research should avail those aspects that add value to quick
\end{abstract}


compromise among stakeholders during construction dispute.

\section{Subject Areas}

Sociology

\section{Keywords}

Construction Team, Proactive Dispute Management, Procurement, Personality Traits

\section{Introduction}

Dispute or conflict is a common phenomenon in construction business which has also caused so many drawbacks in achieving projects objectives [1]. Dispute and conflict have been widely used interchangeably in literature to mean the same thing, despite that dispute has been distinguished and referred to as differences in opinion while conflict is actually dispute where claims have been advanced by a party but rejected by the other [2] [3]. According to Cheng et al. [4], conflict or dispute often damages the reputation of parties, affects work quality as well as delays construction project progress. Delay in construction works itself causes overruns on construction cost [5].

Conflicts or dispute has received some research focus in efforts to not only reduce the negative effects but to also exploit its beneficial tendency for projects success. One key area that received research attention is the linking of personality traits to dispute management (avoidance and quick resolution). Personality is the total of ways in which an individual reacts to situations or interacts with others in daily activities [6]. It consists of those qualities that account for consistent patterns of feelings, thinking and behaving as distinct in a person. Diner and Lucas [7] described traits as those stable patterns of behavior that persist for long and can have broad-ranging consequences for many areas of one's life. More clearly, personality is a set of measurable traits an individual exhibits repeatedly on many occasions, the identity of individuals in terms of relatively stable patterns of behavior, thoughts, and emotions [8]. Personality traits in this research therefore refer to those qualities in individual that dictate the kind of reactions, actions or inactions regards unfolding events as distinct from others.

Traits can shape conflict resolution process in construction [9] because people [10] tend to behave differently in adverse and varied circumstances. A disputant with good personality does enhance dispute avoidance and quick resolution while bad personality can cause complication and prolong dispute resolution [6]. Akiner [11] submitted that understanding the diversity in background of workers within multi-national construction projects can be a serious tool for dispute avoidance between the parties involved. The scholar in a wide literature search, examined the relationship of conflict and culture in respect to the project outcomes, like performance and participants. A recommendation that the primary 
players of the construction industry should be studied in detail was made. Iyiola and Rjoub [12] asserted that the research should dwell on conflict management climate in the construction sector.

Dispute avoidance in a project management context relates to personality in terms of appropriate actions, behaviour and mindsets [13]. Naismith, Sethi, Ghaffarian Hoseini and Tookey [14] observed that there is insufficient in-depth research works to underpin the effect of personality traits on conflicts and its resolution process. However, the personality traits applied to construction dispute resolutions which include integrating, obliging, dominating, evading and compromising have been identified in literature [14] [15]. Rahim [15] studied the personality traits in light of strategies that suits different scenario in conflict management by a third party. Ahmed, Nawaz, Shaukat and Usman (2010) cited by [14] saw it in light of inherent personality traits in individuals that affect conflict management. The scholars posit that disputants with positive agreeableness tend to avoid conflicts, extroverts tend to collaborate while individuals with high openness and conscientiousness are more likely to be competitive. Complementing this aspect of research, it is imperative to inquest the traits of individuals as it affects construction business dispute. In other words, it is to establish if construction disputants assembled from diverse backgrounds are most likely to be compromising, obliging, dominating, evading or integrating in which this work centers. This research becomes imperative because construction related conflict is not only yet to subdue, but is not even likely to improve sooner or later [16]. Research reports avail a consistent trend in increasing duration of disputes resolution with a jump in global average [17]. Possibly, the traits that has been understudied constitute important factor in poor dispute management. Proactive dispute management has been fully indorsed as better approach for construction and the gain for all parties will be in terms of cost and time effect [17]. Gould [18] believes that conflict management requires clear, concise, careful and proper planning. Planning is all about setting out what to do and how best to do it. Knowledge of the general disposition of litigants to disputing matters will contribute immensely to planning and better strategies for conflict management of construction disputes. This work therefore:

1) identifies relevant personality traits and their effect on dispute management;

2) identifies the dominant traits of team members often engaged in dispute during construction works;

3) uses the findings to develop a framework for proactive dispute resolution in construction projects.

It is hoped that the research will offer a system for tackling disputes in terms of prevention and quick resolution.

\section{Literature}

\subsection{The Traits and Their Influence on Individuals}

The social science theories have found diverse traits in human beings which in- 
fluence human disposition to life events on a variety of issues in a variety of ways. For example, traits influence choice among alternatives, reactions to favorable and unfavorable events, general behavior, etc. [19]. The Happenstance Learning Theory (HLT) attempts to explain how and why individuals follow different paths through life's journey, and in that process identifies and explains how traits in individuals are established. The theory explains why human beings do what they do, behave the way they behave, choose the profession they chose or believe in what they believe etc. [19] [20]. These are essentially the products of hereditary and environmental factors [14]. This theory underscores the fact that human beings are not the same in thoughts, actions, reactions and preferences, but are influenced in one way or the other by certain factors in life that lead to doing different things including their dispositions in conflicts and responses to management strategies. Therefore, when human beings meet or come together for whatever reason, there is that high tendency of traits manifesting in their day to day relational activities. While some traits exhibited by individuals may enhance harmony and smoothen processes of production, others lean towards disharmony and impeding it [21] [22], this therefore remains an important factor when managing situations. This paper premises that understanding the traits inherent in an individual can enable a better way of dealing with situations surrounding that person. Understanding the traits in construction team members can therefore enable better approach in managing dispute issues among team members.

\subsection{The Construction Conflicts Management and Traits of Parties}

The presence of impediments necessitates the need for management in process flow. The human factor in management is often accompanied with tendencies of causing impediments to management success. Stakeholders in the construction sector are many and do get involved in the construction production process [23]. Human factors like conflicts have caused management impediments through wrong human interactions or dispositions [1]. The stakeholders interact in a project-based production environment pursuant to a common goal [24] and each with associated traits. These traits manifest and come to bear during production processes. Some stakeholders come into construction business as individuals while others are engaged as organisational clusters (e.g. client cluster, contractor cluster, consultants cluster and various trades' gang men, etc.), [25], all in the pursuit of the common goal. The distinct cluster backgrounds often affect one's traits [11] as such each cluster may equally exhibit distinct traits during interactions in the construction environment. Construction therefore experiences diverse individuals' traits as well as groups' traits exhibited in behavioral pattern during procurement process. Such differences [8] [14] are not only sources of dispute in the sector, but could pause difficulty in quick dispute resolution when dispute arises. The clusters have diverse cultures and the individuals are of diverse professional leaning. Still there are those highly educated, poorly 
educated and those not educated at all. Each group of people has contributions to make and do mingle together during production process. Divakar and Kumar [2] and [25] believe that these backgrounds influence the traits and do also affect the kind of interest and priorities each person places and pursues in construction procurement. These diverse interests are a major source of construction dispute during construction contract implementation. Conflict or dispute therefore is not only a common occurrence in construction production (1) but cuts across the vertical and horizontal construction organizational structure [16] [26]. Five levels of conflict prevailing in construction organisations were reviewed by [16] including intrapersonal, inter-personal, intra-group, inter-group and intra-organizational levels conflicts. The scholars described the intra-personal as a kind of conflict within the mind of an individual, the inter-personal is a conflict that arises between two or more individuals who have divergent or opposite outcomes (goals), attitudes, values or behavior and fail to share the same views, and have different interest or goals. Intra-group conflict refers to conflicts of the same team and group members. Through groups interactions within the same organization inter-group conflicts can arise based on divergence in some variables that are more or less related to the progress of the organization, and the conflict can be formal or informal in nature. Notably, groups differ in goals, work activities, power and prestige. Intra-organizational which varies from organization to organization occurs between parties within an organization and may concern the structure of the organization, the location of formal authority and the way in which jobs are designed. The probability of escalated conflicts increases when people from different backgrounds, ideas and values work together in a social network [26]. For example, quantity surveyors, architects and engineers are different clusters within the same organization that could share different opinions leading to conflicts. The conflict ladder (Figure 1) tries to explain how small conflict could escalate having been influenced by traits and poor management.

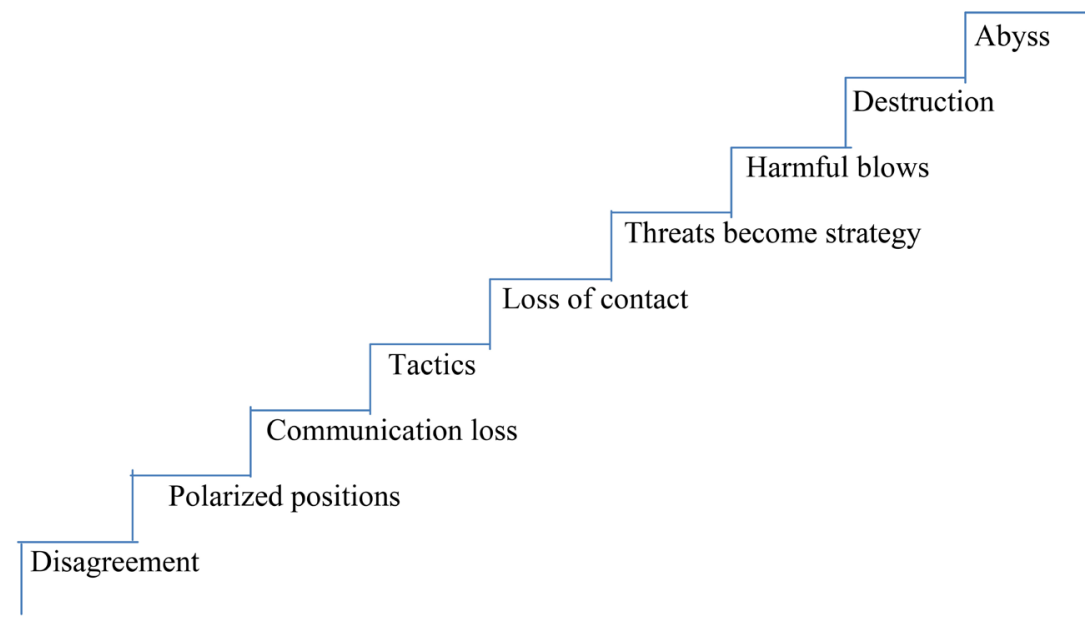

Figure 1. Conflict ladder (Glass1, 1982 in 26). 
As such, [26] described six types of conflicts arising from the differences among disputants. According to [26], fundamental disagreement can occur from differences in interpretations of verbal or non-verbal communicative acts called interpretation conflicts; but when the disagreeing parties endorse incompatible arguments or see the strength of arguments differently it leads to argumentation conflict. However, parties pursuing different ideals considered of greater value it is called value conflicts. When seeking to achieve different aims at personal or group levels, interest conflicts occur. Role conflicts occur when there is lack of clarity or disagreement about formal or informal roles; and finally, personal conflicts are disagreement grounded in perceptions of unacceptable personality traits or attitudes. Therefore, [27] conflict exists when people differ, or have different ideas about value, as well as different answers to something that requires resolution.

Construction scholars evidence how differences in human nature affect construction conflicts management. In a literature based research, Botha (2000) cited by [28] established how the basic differences in value between people influence dispute management. These include the profession and skills of an individual, kind of expectations by parties, emotions, the educational background and level of the individual. Similarly, [11] examined the relationship between conflict and culture in respect to the multinational construction project outcomes. The scholar understood such projects to consist of workers from various cultural backgrounds. The theory was that the backgrounds determine the traits and affecting behaviours of individuals in construction. It was found that culture plays an important role in achieving understanding and gaining cooperation between participants in construction conflict management, and in turn affecting productivity. This idea was earlier muted by Mohammed et al. (2008) cited in [29]. Narh et al. [29] described Nigeria as a multi-ethnic groupings nation, making the country prone to ethnic related causes of construction conflicts. The ethnic background factor creates differences in individuals leading to differences in behavior. According to [30], the behavior of an individual is the manifestation of traits. Traits therefore become fundamental in describing one's personality and often affect not only the consistency but pattern of behavior, feelings and thinking, and such behaviors and feelings have often manifested during conflict management efforts.

More succinctly summarised, construction is complex due to its project-based activity which demands contributions from multiple parties, among numerous organizations and individuals, but each party also focusing on unique interests during the implementation of a project [25]. The backgrounds create various traits among individuals and often complicate construction conflict management. Construction related conflict therefore [5] is of unusual difficulty and more complexity to manage. This narration however presents a template so prone to conflicts.

\subsection{Dispute Management and Traits of Construction Teams}

Dispute or conflict in construction is not entirely a disadvantage, rather, it is the 
poor management that causes greater concern. This has made researchers to document ways in which dispute can best be managed to either avoid or derive benefits from it. For example, [18] believed that avoiding dispute is better and attempted to list steps to avoid conflict in construction business entirely. According to the scholar, good management, clear contract terms, partnering and alliance, good project planning and management and also good management of stakeholders remain the key. Believing also that structural interventions in conflict can enhance organizational learning and effectiveness [15] set out to diagnose the appropriate methods of interventions. Through wide literature diagnoses the scholar indicated the need for intervention including a proposal of the kind of intervention needed in diverse kinds of organizational conflicts. The styles of conflicts management that fit different situations have been analysed in line with supervisor's traits in the handling of organizational conflicts [26] [31] [32]. These include dominating, integrating, obliging, compromising, evading, sentimental and optimistic (see Table 1). However, these factors have been viewed beyond mere strategies to include managers' attitudes [33] [34]. Norby [26] argued strongly that it is not all about managers' acumen, understanding of the situation and style employed in dispute management, but the content inclusive. More succinctly, it is not only the manager's knowledge of how best to address conflict and using the best handling technique but the underlying nature of the conflict in question affects management. Further, the content of dispute encompasses everything related to it including the behavior, attitudes or traits of disputants in a management scenario.

In a dispute management model, [26] rather focused on the parties in dispute and asked three questions to guide dispute resolution. That is, if parties have -inconsistent values, incompatible interests or do they disagree about role distribution and areas of responsibility? The essence is to find a common core between disputants as bases of managing the conflict, however, it underscores an emphasis on differences inherent between disputants in diversion from the management styles most researchers do emphasize.

Ige [35] summarized how the outcomes of conciliation are dependent on the willingness of the parties to engage in negotiation and make compromise. According to [35], more recent studies have focused on the attitudes of the parties towards each other, the level of their tolerance of the involvement of an independent third party, and how the action of the parties determines the process and outcomes of dispute resolution. Naismith et al. [14] observed that individual differences in conflicts are a major concern that will shape the conflict resolution process.

The kind of challenges relating to construction dispute calls for a proactive approach as best way to manage it [17]. Managing construction dispute requires both proactive approach and a mindset, which must be implemented as early as possible [13]. Groton and Haapio [36] believed that the standard alternative dispute resolution (“ADR") process is an inadequate dispute management systems because they deal only with the symptoms of disputes that have already 
Table 1. Traits of parties to dispute and effect in the management process.

\begin{tabular}{|c|c|c|c|}
\hline & Traits & Description & $\begin{array}{l}\text { Likely effect on dispute } \\
\text { management }\end{array}$ \\
\hline 1 & $\begin{array}{l}\text { Dominating } \\
\text { (forcing, competing, } \\
\text { dominating) }\end{array}$ & $\begin{array}{l}\text { An attitude where a party has high concern for self and low for the others. Here is a forcing } \\
\text { behavior to win one's position. A person goes all out to win and often ignoring the needs } \\
\text { and expectations of the other party. One enforces own interest even at the expense of those } \\
\text { of the others. Under this situation a litigant will hardly adduce to facts presented as he will } \\
\text { look at it as a shame to accept defeat. }\end{array}$ & Negative \\
\hline 2 & $\begin{array}{l}\text { Integrating } \\
\text { (confronting, } \\
\text { collaborating) }\end{array}$ & $\begin{array}{l}\text { An attitude where a party has high concern for self and also for others. The key attitudes } \\
\text { involve openness, exchanging information and examination of point of divergence to } \\
\text { reach compromise by parties. The party attempts to merge both parties' interests in order } \\
\text { to reach a solution that satisfies both sides at a face to face discussion. }\end{array}$ & Positive \\
\hline 3 & Compromising & $\begin{array}{l}\text { Compromising is an attitude with intermediate concern for self and others. A give and take } \\
\text { attitude is exhibited where parties give up something to make mutual acceptable decision. } \\
\text { This is a give and take approach in order to reach a midpoint agreement. }\end{array}$ & Positive \\
\hline 4 & $\begin{array}{l}\text { Evading } \\
\text { (withdrawal, } \\
\text { Avoiding) }\end{array}$ & $\begin{array}{l}\text { An evading member tends to have low concern for self and also low for others. Here an } \\
\text { evading person is less interested in satisfying his or her own concern as well as the concern } \\
\text { of the other party. The person becomes uncooperative and engages on the evasion of } \\
\text { conflict topic, the other conflict party, or the situation altogether. This situation is capable } \\
\text { of prolonging the dispute resolution time frame. }\end{array}$ & Negative \\
\hline 5 & $\begin{array}{l}\text { Obliging } \\
\text { (yielding, } \\
\text { smoothing, } \\
\text { accommodating) }\end{array}$ & $\begin{array}{l}\text { Obliging is an attitude where a person is having low concern for self and high for others, to } \\
\text { the extent that one can neglect his concern to satisfy the concern of the other person. The } \\
\text { attitudes attempt to play down the existing differences and emphasis laid on common } \\
\text { areas to satisfy the concern of the other party. In general, it accommodates other's interest } \\
\text { on expense of one's own interest just to get the dispute resolved. An obliging situation can } \\
\text { enhance dispute resolution since a disputant is ready to accept unsatisfactory conditions to } \\
\text { get the dispute resolved. }\end{array}$ & Positive \\
\hline 6 & Optimistic & $\begin{array}{l}\text { The optimist always has high and unrealistic expectations during projects delivery. It is } \\
\text { difficult to meet the expectations of such people and everyone can be seen as accomplice } \\
\text { against the person's stance or concern. Under this situation the disputant will reject almost } \\
\text { every proposal including those to his advantage and can change his goal post for higher } \\
\text { demands. This is capable of prolonging dispute. }\end{array}$ & Negative \\
\hline 7 & $\begin{array}{l}\text { Sentimental } \\
\text { (emotional) }\end{array}$ & $\begin{array}{l}\text { This is an attitude where an individual is insincerely emotional and becoming easily upset } \\
\text { on events. Emotional persons can easily react unfairly against issues. This is capable of } \\
\text { breeding more problems and introducing new dimensions into the real issue to solve } \\
\text { through unethical responses to the recent emotional issues. }\end{array}$ & Negative \\
\hline
\end{tabular}

Source: (Rahim, 2002b; Ogunbayo, 2013, Norby, 2018).

developed and need only to be resolved. In contrast, the proactive/preventive methods should be emphasized. The scholars described proactive as preventing problems from occurring, the control of problems and the differences in opinion so they don't escalate into dispute, conflict and legal action. Nguyen [37] developed a model to handle conflicts between joint ventures partners from different backgrounds before the conflict happens and also curing it after it has occurred.

\section{Methodology}

This research adopted a quantitative approach with data obtained through a set of questionnaires distributed to target respondents. Being the key stakeholders, construction dispute is common between clients, contractors and consultants on 
which the questionnaire was administered using a stratified random sampling technique in both organizations located in Kaduna, Kano and Abuja. The essence is to collate data to establish the dominant personality traits among the three groups of stakeholders. While individuals responded to the questionnaires, the conglomerate from each group reflects the general traits in the group. Respondents were expected to assess themselves only as bases of computing the group's mean. This is a limitation for the fact that the opinion of other fellow team members were absent against if the research were to include a situation where the teams assess their counterparts. However, this stance of self-assessment is taken to give a more stringent outcome. Through literature search, seven key personality traits were identified which form the key subject in the questionnaire. Respondents rated the level at which the identified traits factors are present in the affected group. The sample size of the unknown population of the respondents for this research was deduced by using Cochran's formula for calculating sample size i.e.

$$
N_{o}==\frac{Z^{2} P Q}{E^{2}}
$$

where $N_{o}=$ required sample size, $Z=$ selected critical value of desired confidence level (1.96 for 95\% confidence, 1.6449 for $90 \%$ and 2.5758 for $99 \%), P=$ estimated proportion of an attribute that is present in the population (0.5 for 50-50, 0.3 for $70-30), Q=1-p$ and $E=$ desired level of precision $(0.03,0.05,0.1$ for $3 \%$, $5 \%, 10 \%)$.

Under this case, let's be $95 \%$ confident with assumption that the estimated proportion of the attribute that is present in the population to be 0.5 and $5 \%$ precision, then:

$$
N_{0}=(1.96 \times 1.96 \times 0.5 \times(1-0.5)) /(0.05 \times 0.05)=384
$$

Using the above formula, a sample size of 384 was obtained. Adding an error factor, a total of 394 was administered. A total of 267 questionnaires were returned. However, 258 were sorted out and used for the analysis. The valid questionnaires represent over $65.48 \%$ of the total distribution. The questionnaire was divided into two sections. "Section A" deals with the demography of the respondents while "Section B" addresses the main objectives of the research.

To obtain dominant traits factors of the teams, responses were segregated into the three groups of client, consultants and contractors and descriptive statistics used to analyse the data. Using the SPSS package for the data analysis, the mean values and standard deviations of the seven traits in the questionnaire were computed. Mean values suggest dominance of the traits. However, the level of significance of the mean values was established through the $t$-distribution statistical tool with p-values as bases of interpreting the hypotheses. The hypothesis is as follows:

$\mathrm{H}_{0}$ : The traits of domination in clients during dispute is not significant. 
$\mathrm{H}_{1}$ : The traits of domination in clients during dispute is significant.

A 95\% confidence level was adopted such that if a significant value ( $p$-value) computed falls below 0.05 , it indicates acceptance of the not significant hypothesis $\left(\mathrm{H}_{0}\right)$, i.e. such trait is not significant in the group, while values greater than 0.05 indicates rejection of the $\mathrm{H}_{0}$ hypothesis and acceptance of the alternate hypothesis $\mathrm{H}_{1}$ that the trait is significant. Similar hypothesis applies to all the seven traits factors for all the teams.

\section{Discussion of the Results}

\subsection{Demography of the Respondents}

Table 2 reports the results of the demographic analysis of respondents to the research. It describes the quality of respondents. The percentage of each item is obtained by dividing the frequency by the total value of each category and divided by 100 . In accordance with the research design, the questionnaires were distributed and retrieved from clients' organizations about (20.16\%), consultants' (50.78\%) and contractors' (29.07\%). This is in accordance with the research design. All the respondents, irrespective of the organization were educated in the basic construction background driven from architecture (6.20\%), quantity surveying (53.10\%), engineering 26.36\%) and the building profession (14.34\%). The highest group of participants was quantity surveyors who responded on behalf of the organisations they work. From the responses, only $14.3 \%$ of the organizations have existed between 1 to 5 years. The organizations that have existed above 10 years are about $65.88 \%$ while less than $20 \%$ have existed between 5 to 10 years. Also, the years of experience of respondents show that most of them are long in service within the construction sector. Only $18.60 \%$ have served below 5 years. The number that have served above 10 years cumulatively are about $52.62 \%$.

Cumulatively, $74.81 \%$ were either top or mid management personnel, and still $8.53 \%$ are at lower management level. The major part of the respondents was at varying management levels in the organizations they serve. This finding matches rightly with the years of experience of respondents which expectedly might have risen to such positions within the organizational hierarchies through long years of service. Therefore, more respondents are educated and experienced construction practitioners. This research can therefore rely on the responses as valid.

\subsection{The Dominant Traits in Construction Teams}

This section determines the likely common traits of construction team members during dispute matters in construction undertaking in line with the objectives of the research. Table 3 identifies three teams as initially scoped in this work. The choice of teams was based on their dominance on the role played in construction procurement process. They are the client's team, contactor's team and consultants' team. These teams often engage in conflict during procurement activities. This therefore, is to establish the dominant traits in each team, the traits which 
constitute important factors that influence dispute management between parties. Seven possible traits were identified from literature. Respondents rated themselves on a Likert's scale of 1-highly disagree, 2-disagree, 3-neutral, 4-agree, 5-highly agree, regarding the extent to which the identified traits exist within the affected team. Table 3 depicts the results of the analyses.

Table 2. Demography of respondents.

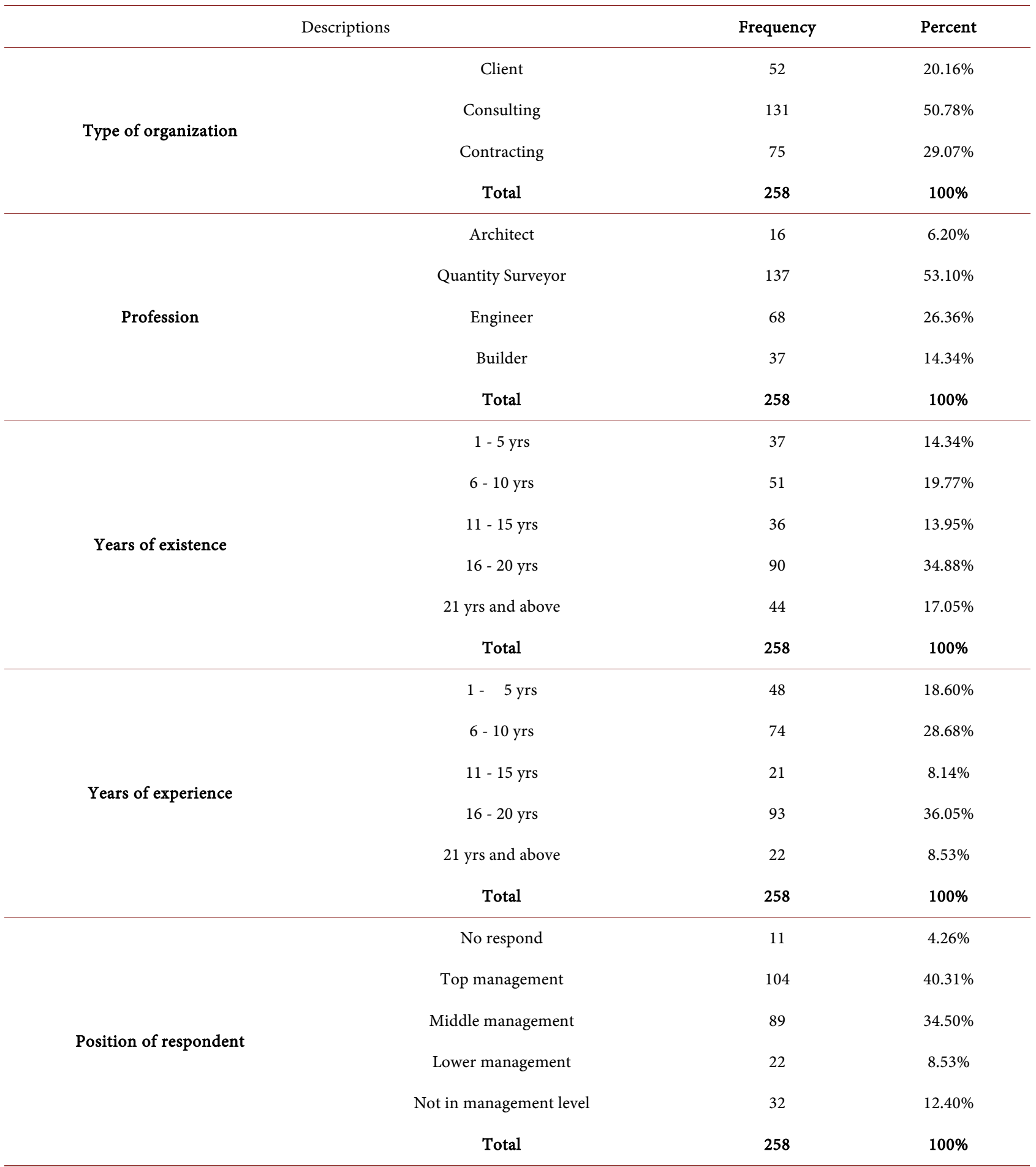




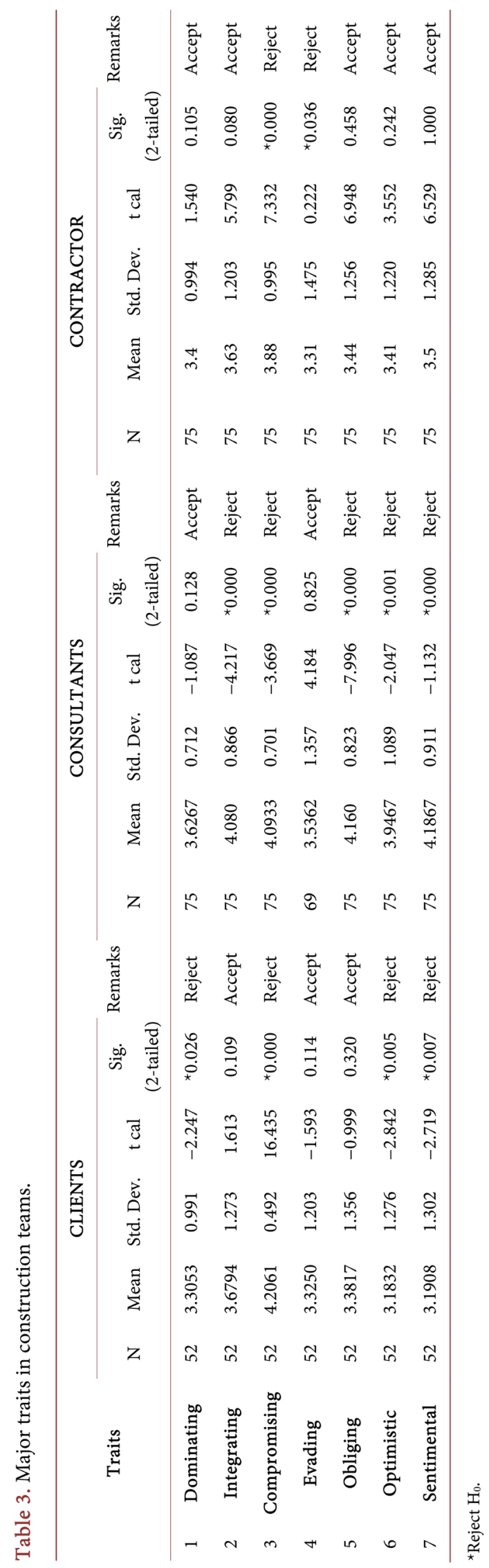


1) Clients' dominant traits: The clients were asked to evaluate themselves and the ratings analysed separately and reported in Table 3 . The highest mean suggests that clients have a high compromising stance (4.2061) on dispute matters, followed by integrating (3.6794). These are good traits in dispute management. On how significant the traits exist among clients group, a set of hypotheses was established. The first hypothesis that "clients do not dominate dispute situations" is the null hypothesis $\left(\mathrm{H}_{0}\right)$ which is the first item in Table 3 , while the alternate hypothesis $\left(\mathrm{H}_{1}\right)$ is "clients tend to dominate dispute situations." The research was therefore set to either reject or accept $\mathrm{H}_{0}$. In Table 3, the p-value indicates that clients have four dominant traits out of the seven identified and studied. The significance value (p-value) for dominating is 0.026 which is less than 0.05 level of significance indicating we reject $\mathrm{H}_{0}$. The value establishes that there is sufficient reason to reject the $\mathrm{H}_{0}$ which states that construction clients are not dominating by their traits. The alternate hypothesis is therefore accepted that clients are dominating during dispute situations. By dominating, clients tend to enforce their own interest and will over their opponents even at the expense of the opponent during dispute resolution.

Other significant traits among clients are that the client is often optimistic (0.005), having high expectations, and also sentimental (0.007), which means, being emotional during dispute. However, there are tendencies of being compromising also (0.000). Apart from being emotional with unrealistic expectations, and optimistic, the domineering traits are possibly the result of being the employer in the sector who then tries to exert authority over employees. The compromising attitudes may come up if it is evident that the work will suffer setback. The results show that client is not integrative (0.109), not evading (0.114) and not obliging (0.320) as all the values are above 0.05 which accepts the null hypothesis. Figure 2 therefore depicts the client's traits factors. Four traits are common in Figure 2 where the connecting points are at the outer circle, which are the ray lines 1,3,6 and 7, while only three are not which are ray lines 2,4 and 5 .

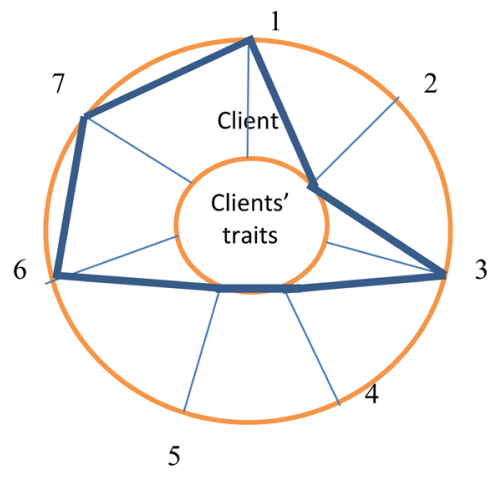

Figure 2. Clients' traits factors. Key: $1=$ Dominating, 2 = Integrating, 3 = Compromising, $4=$ Evading, 5 = Obliging, $6=$ Optimistic, $7=$ Emotional. 
The inner and outer circles signify zero and one levels respectively which also interprets that a particular trait is either significant (1) or insignificant (0) in the clients' team respectively. The bold line graph connects the points of significance levels in the figure. The ray lines 1, 3, 6 and 7 in the figure show that the traits have significant presence in client's team while only 2 and 5 do not.

2) Consultants' major traits: The common traits of consultants during dispute were analysed similar to the way those of the client were analysed in which Table 3 also reports the findings. The highest mean values scored above 4.0 in an order are sentimental (4.1867), obliging (4.1600), compromising (4.0933) and integrating (4.0800). To identify the traits of the consultants existing at a significant or insignificant level, the p-value was used as indicated in Table 3 also. The $\mathrm{p}$-values show that the consultants have five dominant traits significantly present out of the seven studied. Two of the traits have the p-values above 0.05 , these are dominating (0.128) and evading (0.825). it means that for these two traits, we accept $\mathrm{H}_{0}$ which states that there is no significant presence of the traits, thus concluding that consultants are not dominating (i.e. enforcing own interest even at the expense of those of the other party in dispute) and are not evasive (avoiding, i.e. either dodging conflict topics, or dodging the other conflict party, or the situation altogether). However, the value of integrating (0.000), compromising (0.000) and obliging (0.000); and also optimistic (0.001) and sentimental (0.001) are all less than 0.05 level of significance. It means that we reject $\mathrm{H}_{0}$ of no significance but accept $\mathrm{H}_{1}$ which states that there's significant presence of those traits among consultants. This concludes that consultants are often integrating in nature, compromising and obliging by not only accommodating other party's interest during dispute but having high concern for others. However, consultants could be emotional and optimistic, having unrealistic expectations during projects delivery. Figure 3 depicts the consultants' traits factors.

Five traits are dominant in Figure 3 where the connecting points are at the outer circle, which are the ray lines $2,3,5,6$ and 7, while only two are not which are ray lines 1 and 4 .

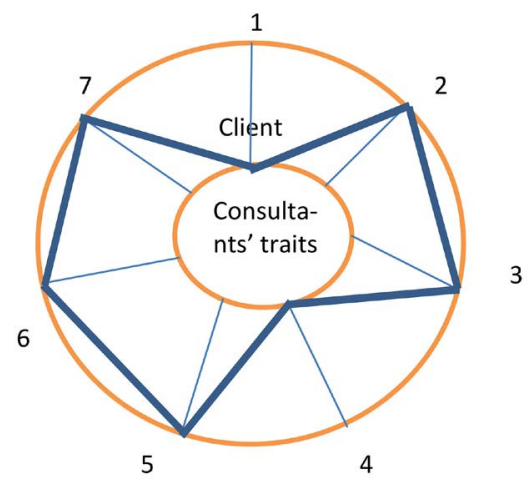

Figure 3. Consultant's traits factors. Key: $1=$ Dominating, 2 = Integrating, 3 = Compromising, $4=$ Evading, $5=$ Obliging, $6=$ Optimistic, $7=$ Emotional. 
3) Contractors: The traits of the contractors are reported in Table 3 also. Expectedly, there seems to be a remarkable difference between the traits of the contractor and those of the client and consultants. Three highest mean values in ranking order of magnitude for contractors are compromising (3.88), integrating (3.63) and sentimental (3.50). On the aspect of significance of the traits, the $\mathrm{p}$-values indicate that the contractor tends not to be dominating (0.105), not integrating (0.080) and also not obliging (0.458). The significant values on the three cases were above 0.05 level of significance, thus presenting enough evidence to accept $\mathrm{H}_{0}$. Furthermore, contractors are not optimistic (0.242) and not sentimental (1.000) on dispute matters. However, contractors are found to have two dominant traits which are evading (0.036) i.e. being evasive on dispute matters, but at the same time they are compromising $(0.000)$, i.e. tending towards a give and take approach in order to reach a midpoint agreement. Figure 4 depicts the contractors' traits factors.

The contractors have two dominant factors out of the seven factors studied which are ray lines 3 and 4 which are connected at the outer circle. The other five factors are connected at the inner circle which are ray lines 1, 2, 5, 6 and 7 showing that they are insignificant factors.

\section{Discussion}

This research was set to establish the major traits of construction teams on dispute matters. Seven patterns of behavior or way of responses to dispute were identified from literature. Understanding the trades will enable proper planning for better dispute management in the sector. Each team was found to have a unique trait that dominates the group in which others do not share. It is evident that only the client tends to be dominating during dispute, only the contractor is evasive and only the consultant is obliging and integrating. The possibility of the client becoming domineering might be influenced by virtue of being the employer/owner of the project who attempts to assert authority and impose his will. Blended with an anxiety to get value for investments, it can also influence the level of the domineering tendency when there is dispute. The table reveals that the client could also be optimistic and sometimes emotional. By implication, the desire for cost, quality and time objectives could influence the exertion of authority, optimism and emotionality on others.

The consultant is the only person found to be obliging and integrating. These traits enhance dispute management in construction business. Even though employed by the client, the consultant serves both parties and tends to be neutral or more loyal to the project than to his employer during construction contracts execution. Consultants do focus more on the success of the project as such most likely to be integrating and obliging to enable smooth project flow. However, the consultants and the client tend to share two similar traits which the contractor doesn't share which are being optimistic and emotional.

The contractor is the only party found to be evading dispute matters. By implication, the contractor dodge the conflict situation altogether which is most 
likely to impede any quick management effort. This is capable of extending dispute resolution time and delaying projects completion entirely. There is a direct relationship between time and cost, the longer the project duration the more likely the cost of the project due to inflation and other market factors. Therefore delay could set in claims by the contractor due to inflation which could be an advantage on his side. The longer the project takes to complete the better for the contractor especially when fluctuations claims are permissible.

To proactively plan, we need to know the mindset of disputants and their behavioral tendencies. Table 4 compares the traits of teams which dictates their behavior when dispute starts. One (1) denotes a significant factor while zero (0) denotes an insignificant factor. Apart from each party having at least one unique trait factor, both parties have one common ground which is a compromising stance. It means that there are circumstances where both parties will compromise dispute stance. This is a positive trait during dispute management. This stance is possibly an understanding to enable the project to move forward. This is a valid finding where management of dispute can rely on issues that will draw a party to compromise and focus on them for quick dispute resolution when they occur.

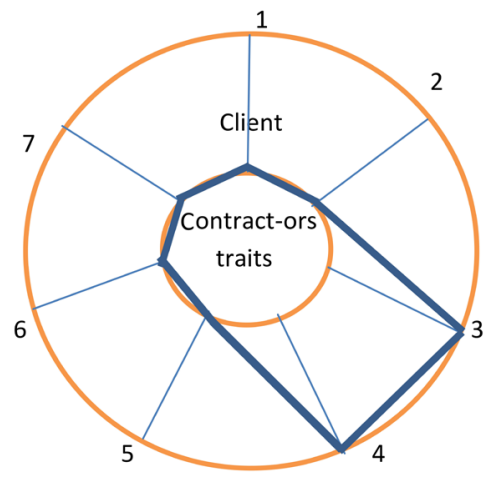

Figure 4. Contractor's traits factors. Key: $1=$ Dominating, 2 = Integrating, 3 = Compromising, $4=$ Evading, $5=$ Obliging, $6=$ Optimistic, $7=$ Emotional.

Table 4. Common traits among construction teams.

\begin{tabular}{lcccc}
\hline & Traits/Team members & Client & Consultants & Contractor \\
\hline 1 & Dominating & 1 & 0 & 0 \\
2 & Integrating & 0 & 1 & 0 \\
3 & Compromising & 1 & 1 & 1 \\
4 & Evading & 0 & 0 & 1 \\
5 & Obliging & 0 & 1 & 0 \\
6 & Optimistic & 1 & 1 & 0 \\
7 & Emotional & 1 & 1 & 0 \\
\hline
\end{tabular}

Key: $0=$ not significant, $1=$ significant. 


\section{Conclusion and Recommendation}

To proactively manage, we need to know the mindset of disputants or their behavioral tendencies. This research has identified the traits of team members which influence their behavior when dispute arises. There is at least one unique trait identified within each group that is not shared by another. While the client is not evasive but domineering, possibly, pushing for quick dispute resolution, the contractor is more evasive, knowingly that the longer the time a project takes to finish the better for fluctuation claims. The consultants on their part are obliging and integrating, i.e. often accommodating other party's interest on expense of their own interest. Even though employed by the client, consultants' ethics demand to play an impartial role during construction undertaking, if possible, be more loyal to the project than to the employer. This therefore reflects a mediatory responsibility where the consultant will try to aid quick dispute resolution for the interest of the project irrespective of whether there are personal gains or not. The general conclusion here points towards the fact that the background of a team member, vis-à-vis the basic services rendered does affect the kind of response to dispute as earlier established by Akiner (2014) [11] and Naismith et al. (2016) [14]. Interestingly, both parties have a high tendency to compromise to enable work progress. These pieces of information avail foreknowledge of likely behavior of a disputant which can help in dispute avoidance as well as in quick resolution. Simple disputes will better be managed so as not to grow into serious issues. The findings can benefit disputants on strategy to approach an opponent when dispute arises having known his traits. Mediators on dispute will also use the findings to design a strategy to bring disputants to quick resolution having known each party's antecedents. Further research should identify factors of compromise during dispute matters in construction.

\section{Conflicts of Interest}

The authors declare no conflicts of interest regarding the publication of this paper.

\section{References}

[1] Ejohwomu, E.A., Oshodi, O.S. and Onifade, M.K. (2016) Identifying the Critical Causes of Conflict in Construction Projects in Nigeria. Nigerian Journal of Technology, 35, 290-296. https://doi.org/10.4314/njt.v35i2.8

[2] Divakar, K. and Kumar, S. (2015) Study on Sources of Disputes in Construction Projects, to Incorporate Suitable Clauses in Contract for Dispute Resolutions. International Research Journal of Engineering and Technology, 2, 455-459.

[3] Akinradewo, O.F. (2017) Assessment of Dispute Resolution in the Construction Industry in Lagos State, Nigeria. Journal of Economics and Sustainable Development, 8, 22-27.

[4] Cheng, M., Tsai, H. and Chiu, Y. (2009) Fuzzy Case-Based Reasoning for Coping with Construction Disputes. Expert Systems with Applications, 36, 4106-4113. https://doi.org/10.1016/j.eswa.2008.03.025 
[5] Sakate, P. and Dhawale, A.W. (2017) Dispute Resolution Mechanism in Commercial Construction Projects: A Review. International Journal of Engineering Sciences \& Research Technology, 6, 84-88. https://doi.org/10.5281/zenodo.268687

[6] Robbins, S.P. (2005) Essentials of Organizational Behavior. 8th Edition, Prentice Hall, Upper Saddle River.

[7] Diener, E. and Lucas, R.E. (2020) Personality Traits. In: Biswas-Diener, R. and Diener, E., Eds., Noba Textbook Series: Psychology, DEF Publishers, Champaign, IL, 4-11. http://noba.to/96u8ecgw

[8] Parks-Leduc, L., Feldman, G. and Bardi, A. (2015) Personality Traits and Personal Values: A Meta-Analysis. Personality and Social Psychology Review, 19, 3-29. https://doi.org/10.1177/1088868314538548

[9] Yiu, T.W. and Lee, H.K. (2011) How Do Personality Traits Affect Construction Dispute Negotiation? Study of Big Five Personality Model. Journal of Construction Engineering and Management, 137, 234-255. https://doi.org/10.1061/(ASCE)CO.1943-7862.0000271

[10] Atalah, A. (2013) Comparison of Personality Traits among Estimators, Project Managers, and the Population. Journal of Management in Engineering, 30, 173-179. https://scholarworks.bgsu.edu/construct mgt pub/5 https://doi.org/10.1061/(ASCE)ME.1943-5479.0000209

[11] Akiner, I. (2014) Critical Viewpoints on the Management of Conflict in Multi-National Construction Projects. Organization, Technology \& Management in Construction: An International Journal, 6, 1038-1046. https://doi.org/10.5592/otmcj.2014.2.6

[12] Iyiola, K. and Rjoub, H. (2020) Using Conflict Management in Improving Owners and Contractors Relationship Quality in the Construction Industry: The Mediation Role of Trust. SAGE Open, 10, 1-14. https://doi.org/10.1177\%2F2158244019898834

[13] Mckechnie, I. (2008) Staying out Proactive. Global Africa Projects (GAP) and Innopro, South Africa, 60-61.

[14] Naismith, N., Sethi, R., Ghaffarian Hoseini, A. and Tookey, J. (2016) Managing Conflict in Engineering Projects: New Zealand Experiences. International Journal of Construction Supply Chain Management, 6, 19-34. https://doi.org/10.14424/ijcscm601016-19-34

[15] Afzalur Rahim, M. (2002) Toward a Theory of Managing Organizational Conflict. The International Journal of Conflict Management, 13, 206-235. https://doi.org/10.1108/eb022874

[16] Femi, O.T. (2017) Causes and Effects of Conflict in the Nigerian Construction Industry. International Journal of Technology Enhancements and Emerging Engineering Research, 2, 7-16. https://www.researchgate.net/publication/317952946.

[17] Greenwood, D. and Roe, M. (2016) Proactive' Construction Dispute Management Needed to Ensure Swift Resolution, Experts Say. https://www.pinsentmasons.com/out-law/analysis/proactive-construction-disputemanagement-needed-to-ensure-swift-resolution-experts-say

[18] Gould, N. (n.d.) Conflict Avoidance and Dispute Resolution. RICS QS \& Construction Standards-GN 91/201, Royal Institution of Chartered Surveyors, London. www.fenwickelliott.co.uk

[19] Krumboltz, J.D. (2008) The Happenstance Learning Theory. Journal of Career Assessment, 17, 135-154. https://doi.org/10.1177\%2F1069072708328861

[20] Mitchell, K.E., Levin, A.S. and Krumboltz, J.D. (1999) Planned Happenstance: Constructing Unexpected Career Opportunities. Journal of Counseling \& Development, 
77, 115-124. https://doi.org/10.1002/j.1556-6676.1999.tb02431.x

[21] Suleiman, W. (2013) A Study of Causes of Poor Attitude to Work among Workers of Both Public and Private Sectors Organizations in Bauchi State-Nigeria. International Journal of Academic Research in Business and Social Sciences, 3, 143-152. https://doi.org/10.6007/IJARBSS/v3-i7/16

[22] Webber, J.K., Ser, E. and Goussak, G.W. (2015) Work Habits as Positive and Negative Influence on Workplace Productivity. Global Journal of Business Research, 9, 39-48.

[23] Alazemi, M.K.E., Mohiuddin, A.K.M. and Al-Juboori, S.A. (2019) Conflict Management of Construction Projects-A Case Study: Kuwait International Airport Cargo City. International Journal of Mechanical Engineering, 8, 45-54.

[24] Tabish, S.Z.S. and Jha, K.N. (2012) Success Traits for a Construction Project. Journal of Construction Engineering and Management, 138, 1131-1138.

https://doi.org/10.1061/(ASCE)CO.1943-7862.0000538

[25] Rauzana, A. (2016) Causes of Conflicts and Disputes in Construction Projects. IOSR Journal of Mechanical and Civil Engineering, 13, 44-48.

https://doi.org/10.9790/1684-1305064448

http://www.iosrjournals.org

[26] Norby, H. (2018) Management and Conflict Resolution: Conceptual Tools for Securing Cooperation and Organizational Performance. IntechOpen, London. https://doi.org/10.5772/intechopen.72132

[27] Titov, E., Virovere, A. and Kuimet, K. (2018) Conflict in Organization: Indicator for Organizational Values. IntechOpen, London.

https://doi.org/10.5772/intechopen.75496

[28] Bvumbwe, C. and Thwala, D.W. (2011) An Exploratory Study of Dispute Resolution Methods in the South African Construction Industry. International Proceedings of Economics Development and Research, 21, 32-36.

[29] Narh, O.C., Owusu, E.E., Oduro-Apeatu, K. and Narh, T.J. (2015) An Exploratory Study of Professional Conflicts and Disputes within the Construction Industry. International Journal of Managerial Studies and Research, 3, 44-65. http://www.arcjournals.org

[30] Daud, Z., Yahya, K.K., Isa, M.F.M. and Noor, W.S.M. (2011) The Influence of Heads of Department Personalities on the Selection of Grievance Handling Styles. International Journal of Humanities and Social Science, 1, 241-252.

[31] Afzalur Rahim, M., Psenicka, C., Polychroniou, P., Zhao, J., Yu, C., Anita Chan, K., et al. (2002) A Model of Emotional Intelligence and Conflict Management Strategies: A Study in Seven countries. The International Journal of Organizational Analysis, 10, 302-326. https://doi.org/10.1108/eb028955

[32] Ogunbayo, O.M. (2013) Project Managers' Conflict Management Styles and Its Impact on Project Team Motivation in Nigerian Construction Industry. International Journal of Scientific \& Engineering Research, 4, 2248-2257. http://www.ijser.org

[33] Thomas, K.W. (1976) Conflict and Conflict Management. In: Dunnette, M.D., Ed., Handbook in Industrial and Organizational Psychology, Rand McNally, Chicago, 889-935.

[34] Rahim, M. (2011) Managing Conflicts in Organizations. Routledge, New York.

[35] Ige, A.Y. (2017) Understanding the Nature and Process of Alternative Dispute Resolution and Collective Conciliation: Lessons from United Kingdom, Canada, South Africa and Japan. International Business Research, 10, 103-110. 
https://doi.org/10.5539/ibr.v10n11p103

[36] Gordon, J.P. and Haapio, H. (2007) From Reaction to Proactive Action: Dispute Prevention Processes in Business Agreements.

https://www.researchgate.net/publication/242148632

[37] Nguyen, H.L. (2011) Partnership Strategies: Pro-Active and Pre-Active Approach in Conflict Management in International Joint Ventures. International Journal of Business and Management, 6, 38-45. https://doi.org/10.5539/ijbm.v6n9p38 